\title{
DEVELOPING AN ENGLISH SYLLABUS FOR D3 CIVIL ENGINEERING STUDENTS OF ITS SURABAYA
}

\author{
Umi Trisyanti*
}

\begin{abstract}
Abstrack
The objective of this study is to develop the English syllabus for D3 Civil Engineering Department. The subjects, therefore involves the students, the subjects specialist, and the English teachers. To get the data of students needs, the questionnaire, interview, document and observation were implemented. Research and Development (R \& D) was adopted as the research design, while the model of the development was Language Program Development by Yalden. The most important stage in this study is the needs survey to find out the real needs and interest of those involved in the program as it is the bases for the development. The needs survey was done by distributing questionnaires to the students, subject specialist and the English teachers as the subject of the study. They were asked to respond to the questionnaires. As the product will be implemented in the D3 Civil Engineering program, the syllabus should be validated by the expert in the syllabus design as well as the teacher of the department who has the mastery of the content to check the appropriateness of the topics in the syllabus with the subjects of the field being discussed. Revision was made based on the comments and suggestions given by the experts. Further verification was conducted by trying out the syllabus to the English teachers to make lesson plans based on the proposed syllabus. Based on the findings of needs survey and the result of the development, some suggestions are recommended. ESP is different from general English and it needs careful preparation in the teaching and learning process. English teachers should always collaborate with the subject specialist in determining the syllabus and the material
\end{abstract}

Keywords: syllabus, D3 Civil Engineering

\section{Background}

Teaching and learning English as a foreign language is a very complex activity. It requires methods and materials suitable for particular learners to reach instructional objectives. Teachers and classroom environment also play an important role to bring learners to gain what they want. Some key factors of the success of learning English are learning objectives, the learner, the teacher, materials, methods, and environment (Richards, 2001:123).

Instructional materials are one of the factors that determine the success of learning. They are simply defined as content of learning. Different materials will imply different methods and role relationships between the teacher and the learner (Richards and Rogers, 1986:25).

\footnotetext{
* Dosen UPM Soshum ITS
} 
Teachers also determine the success of learning. It means that their attitude and behavior inside and outside classroom would contribute to the process of learning.

In tertiary level, however, English teaching is applied in two purposes. The first is that English is taught as a foreign language program which teaches the four language skills known as English for general purposes (EGP). The second is that English is given to the students with specific ultimate goal to enable them to understand English written texts in their field of study. This is known as English for specific purposes (ESP) (Hutchinson \&Waters, 1989:6). Compared to the idea of EGP, ESP which has been implemented in many universities in Indonesia is relatively new. Universities have various policies in implementing it. The programs are normally offered in one semester for two credits.

Teaching English at the tertiary level for the non English department students is still concentrated on the need for the capability of reading relevant textbooks. The teaching of English is focused on the development of reading skills which will reinforce the mastery of basic vocabulary. The ESP program has been developed at university level and in occupational settings (Richard, 2001:28). This is especially intended to meet particular instructional objectives such as to enable students to read English texts in the students' field of study, to write laboratory reports, and to make presentations.

In the case of the students of D3 civil engineering department, they usually are not highly motivated and show negative attitude in studying English as it is categorized as a non-skilled basic subject for them. Teachers, especially the inexperienced ones, often face a significant problem in delivering content-based instruction (CBI) because of their lack of content schema in the subjects. Most English teachers are of educational program and not supplied with the content knowledge of the subject being taught. This condition has led a more serious problem of teacher' decision in developing the syllabus and in constructing instruction materials. So far the existing syllabus mostly deals with the general English that gives a little portion of the discussion on topics of students' need and interest. As far as the development of the syllabus is concerned, it still needs re- 
assessment to find out whether the syllabus developed has already been in accordance with the real needs of graduates. The existing syllabus is not suitable because there is no observation about the student' needs on the field done by the English teachers prior to the development of the syllabus. So this turns into the link and matches the requirement in the market demand and improves the quality of professional education based on their competences.

A combination of content-based and competency-based approaches is used in designing the syllabus for D3 Civil Engineering students of ITS Surabaya. The content-based was chosen to maintain the learners' motivation in learning English and to encourage them to be more active, The Content-based instruction reflects learners' needs for learning a second language while the competency-based is chosen to enable lecturers to reach the goal in teaching through the achievement of the stated indicators. ESP course seeks to serve the language needs of learners who need language in order to carry out specific roles and who thus need to acquire content and real-world skills through the medium of a second language rather than master the language for its own sake.

In relation to the above case faced by the staff and the designers at D3 program in ITS, the available English syllabus does not meet the needs of English in the real working condition. An ESP syllabus is needed to develop in order to meet the students' needs. The lack of a suitable syllabus is a reason for the writer to design a syllabus.

\section{Theoretical Review}

The term curriculum and syllabus has been defined in numerous ways. The distinction between curriculum and syllabus is not a major concern, but generally what is usually assumed is that curriculum includes syllabus, not vise versa (Krahnke, 1987: 2). Curriculum development is a contextually enlarged view of syllabus design.

A curriculum may consist of a set of topics concerning an educational program while syllabus consists of a set of topics concerning a particular course. So in the field of ESP, ESP program may consists of one or more ESP courses. 
A syllabus is an expression of opinion on the nature of language and learning, it acts as a guide for both teacher and learner by providing some goals to be attained. At its simplest level a syllabus can be described as a statement of what is to be learnt. This is a rather traditional interpretation of syllabus focusing as it does on outcomes rather that process. However a syllabus can also be seen as a summary of the content to which learners will be exposed (Yalden, 1987:18). The main components of a syllabus are competence standard, basic competence, indicators, material, time allotment, and assessment.

Most syllabi usually have one dominating type and use a combination of other types of content. Krahnke (1987:10) differentiate types of syllabi as follows: Structural/Formal Syllabus, Notional/Functional Syllabus, Situational Syllabus, Skill-based Syllabus, Task-based Syllabus, Content-based Syllabus, CompetencyBased Syllabus.

Syllabus which is used to develop ESP language teaching program has to reflect two dimensions, there are approach and design. Approach is a theory of language and language learning. Design concerns with the specification of actual content and a description of the role of teacher, learner, and teaching materials.

\section{Research Method}

In line with the title of the thesis, developing the syllabus can be categorized as the educational research and development $(\mathrm{R} \& \mathrm{D})$. It represents a series of circle in which a particular product on education such as syllabus and material development is made on the basis of needs survey (Borg \& Gall, 1983: 624). Borg and Gall define R \& D as the process used to develop and validate educational products.

The development of syllabus was conducted on the basis of Yalden's design named Language Program Development (Yalden, 1987:88). The model was a stepby-step procedure in developing a language program. It covers (1) need survey, (2) description of purpose, (3) selection or development of syllabus type, (4) production of a proto syllabus, (5) production of a pedagogical syllabus, (6) try out, and (7) evaluation. 
Description of stages on syllabus development

\begin{tabular}{|c|c|c|}
\hline No & Stages & Description \\
\hline 1 & Needs survey & $\begin{array}{l}\text { - conducting observation, interviewing, and } \\
\text { distributing } \\
\text { - distributing questionnaire to students who } \\
\text { take the ESP and teachers who teach the ESP } \\
\text {-analyzing the collected data }\end{array}$ \\
\hline 2 & Describing the purpose & $\begin{array}{l}\text {-determining the students' characteristics } \\
\text {-determining the objectives of the program } \\
\text {-determining the students' skills on exit from } \\
\text { the program }\end{array}$ \\
\hline 3 & Selecting the syllabus type & $\begin{array}{l}\text {-listing syllabus type best suited and language } \\
\text { use to be covered in the program }\end{array}$ \\
\hline 4 & Production of proto syllabus & $\begin{array}{l}\text {-Listing and describing language and language } \\
\text { use to be covered in the program based on the } \\
\text { students' preference collected through } \\
\text { questionnaire and interview to teacher and } \\
\text { students. }\end{array}$ \\
\hline 5 & $\begin{array}{l}\text { Production of pedagogical } \\
\text { syllabus }\end{array}$ & $\begin{array}{l}\text {-Writing syllabus content, the objectives, the } \\
\text { materials, the strategies, the evaluation, and } \\
\text { time framework }\end{array}$ \\
\hline 6 & Try-out & $\begin{array}{l}\text { The revised syllabus needs to be tested to get to } \\
\text { know whether it is clear enough, } \\
\text { understandable, applicable, and practical or } \\
\text { not. The try out is done by asking the English } \\
\text { teachers to construct lesson plans based on the } \\
\text { syllabus design. }\end{array}$ \\
\hline 7 & Evaluation & $\begin{array}{l}\text { - Asking education experts to give their } \\
\text { feedback on the syllabus (Expert Judgments) } \\
\text { - Revising the syllabus based on the feedbacks } \\
\text { from the expert } \\
\text {-Try-out to get comments and feedback from the } \\
\text { students, teachers, and subject specialists } \\
\text { (Field Try-out) } \\
\text { - Revising the syllabus based on the feedbacks }\end{array}$ \\
\hline
\end{tabular}

The study was conducted at the first year of D3 Program of Civil Engineering students of 2008/2009 academic year in ITS Surabaya. The subjects of the study were the English students in the second semester, the students who have completed English, the English teachers, and the subject specialists.

The data of the study were the responses of the students, the lecturers, and the subject specialist to the given questionnaire and the conducted interviews. The data were also from document collection such as strategic and operational plans of the institution and the curriculum. 
Three types of instrument were used to collect the data namely: questionnaires, interview, and documents. These instruments are based on Olshtain (1986) that in the situation in which there was no syllabus, the syllabus design was based on the information gathered in the fact finding, needs survey, through material in use, teachers, and students.

The data collection in this research conducted in two sections. Firstly, it was executed before the development of the syllabus in order to get the basis for the development. Secondly, it was done after the development of the syllabus to verify the product

\section{The Result of The Development}

The data collected are analyzed in descriptive qualitative. The data from the questionnaire is analyzed descriptively as well as the descriptive analysis is applied to analyze the results of the interviews and the availability of the documents.

The survey was carried out on $1^{\text {st }}$ until $3^{\text {rd }}$ June 2009 at the D3 Civil Engineering department in which 115 copies of questionnaire consists of 14 questions were distributed to the second semester students, 28 questionnaire consists of 8 questions were asked to the students who have completed English teaching and learning, 8 questions were asked to three subject specialists and 9 questions were delivered to three English teachers. All questions were directed to find out the information about the students' needs and expectation while the involvement of the subject specialist and the English teachers turned out to be of great benefit in giving the details of the development of the syllabus for D3 Civil Engineering Students.

From the result of needs survey, it can be concluded that the goal of the study is to equip students with the ability to understand written texts and produce oral and written form of communicative functions of English on their field of study.

Based on the above goal, it can be inferred that the students are required to have the following skills: 1) they are able to understand textbooks, manual instructions, and interpret table and graph ( reading), 2) they are able to produce orally their ideas about general knowledge and more important about the topics 
related to their field of study (speaking), 3) they are able produce the ideas in written form (writing), and 4) they are able to understand spoken utterances ( listening).

The syllabus of English for Civil Engineering is written as a reflection of the needs of those involved in the success of the course; the students, the subject specialists, the language teachers, the department, and the institution. As the syllabus is based on the content, the order of delivering the language is organized based on the function of the language needed to understand the content. The department allocates the course to be completed in 16 weeks in one semester; however the effective learning process takes only 13 weeks as the other three weeks are spent for quizzes and final test.

Based on the competencies that should be achieved by the learners, the topics proposed are classified into 9 units. The topics are selected to match with the content subjects being discussed in the second semester to support their understanding of the textbooks and to supply them with the ability to produce and express ideas of their content subjects in English. The topics and the distribution are presented in this table

\begin{tabular}{|l|l|l|}
\hline Unit & Topics & Session \\
\hline 1 & Introduction to English for Civil Engineering & 1 \\
& Surveying & 2 \\
2 & Basic Architectural Structure & 2 \\
3 & Hydraulic Engineering: Dam \& Canal & 1 \\
4 & Irrigation & 1 \\
5 & Reservoir & 1 \\
6 & Transportation System & 2 \\
7 & Modern transportation & 2 \\
8 & Rigid Pavements & 1 \\
9 & & 13 \\
\hline & Total & \\
\hline
\end{tabular}

The learning experience in this syllabus is planned to be learners' centered activities in which learners are explored to maximize their capacities to achieve the target competence.

Reading skill emphasizes on comprehending the texts by identifying the main idea and the supporting details, answering the questions of the texts, and summarizing the texts. An ability to read and interpret the tables or graphs is also given as mostly textbooks of engineering subjects discuss these points. 
Speaking is intended to motivate learners to be brave enough to express their ideas. Learners are asked to synthesize the texts in their own words and express those texts orally. Sometimes learners are also asked to tell their knowledge about certain topics and discuss with their friends.

Writing activities focus on the ability to produce simple paragraph. The topics of the writing assignment deal with the activities the learners involved such as write a report of an experiment or process of workshop and laboratory.

Listening is done in the class for an hour. The materials consist of general and specifics topics of engineering studies.

To measure the success of the course, an assessment should be implemented. As the goal of the course is to understand and produce the oral and written form of communicative functions of English, the most suitable types of English assessment are the paper and pencil test and the performance one. Paper and pencil tests are applied for written form, while the performance is shown in the form of presentation, participation in the discussion, and answering the questions.

Having analyzed the data, it can be concluded that the proposed syllabus is more appropriate to be implemented than the existing syllabus. The differences of both syllabi are presented in the table below:

\begin{tabular}{|l|l|l|}
\hline NO & THE EXISTING SYLLABUS & THE PROPOSED SYLLABUS \\
\hline 1 & General topics & Content-based \\
\hline 2 & Teachers' judgment & Need survey \\
\hline 3 & Stressed on reading & Included the four skills \\
\hline 4 & Focus on language/ grammar & $\begin{array}{l}\text { Language is selected based on its use to } \\
\text { explain content }\end{array}$ \\
\hline
\end{tabular}

\section{Conclusion}

To answer the problem of the study, an appropriate syllabus for an ESP course for students of D3 Civil Engineering program is developed and completed with the model of lesson plan for each unit. This proposed syllabus is a combination of content-based and competency-based approaches with the consideration that the two approaches are best suited with the needs of the learner's background knowledge. The content-based was chosen to maintain the learners' motivation in learning English and to encourage them to be more active, while the competency- 
based is chosen to enable lecturers to reach the goal in teaching through the achievement of the stated indicators. The element of the syllabus is include the basic competence, the indicators, the materials, the teaching and learning activities, the time allotment, the evaluation and the sources. The availability of an appropriate syllabus in a language program makes lecturers easy to transform the process of teaching and learning into activities in the classroom.

The proposed syllabus was considered as a complete guideline after validate by the expert and subject specialist in the field of Civil Engineering. The syllabus has been tried-out by asking the English lecturers to make lesson plans based on the syllabus. For the aspect of readability and understandability, the syllabus is developed in the column format to make it easier to be transferred into lesson plans.

\section{References}

Ary, D. et al. 2002. Introduction to Research in Education. Wadsworth Australia

Astika, G.1999. The Role of Needs Analysis in English for Specific Purposes. TEFLIN JOURNAL Vol. X Number 1 August, 1999

Borg, W.R. and Gall, M.D. 1983. Educational Research: An Introduction ( $3^{\text {rd }}$ ed) New York: Longman, Inc

Brown, H. D. 2001. Teaching by Principles. An Interactive Approach to Pedagogy, New York: Addison Wesley Longman, Inc

Brumfit, C.J. 1984. General English Syllabus Design. Oxford: Pegamon Press

Civil Engineering Department, 2005, Laporan Akhir Kurikulum Jurusan Teknik Sipil ITS. Surabaya: Institut Teknologi Sepuluh Nopember (ITS)

Dubin, F and Olshtain, E. 1986. Course Design. New York: Cambridge University Press

Gonzalez, D and St.Louis, R. 2002. Content-Based Instruction in Higher Education Settings. New York: Capitol Communication System, Inc

Graves, K. 1996. Teachers as Course developers. New York: Cambridge University Press 
Krahnke, K. 1987. Approaches to Syllabus Design for Foreign Language teaching. New Jersey: Prentice- Hall, Inc

Yalden, J. 1987. The Communicative Syllabus: Evolution, Design, and Implementation. New Jersey: Prentice Hall 